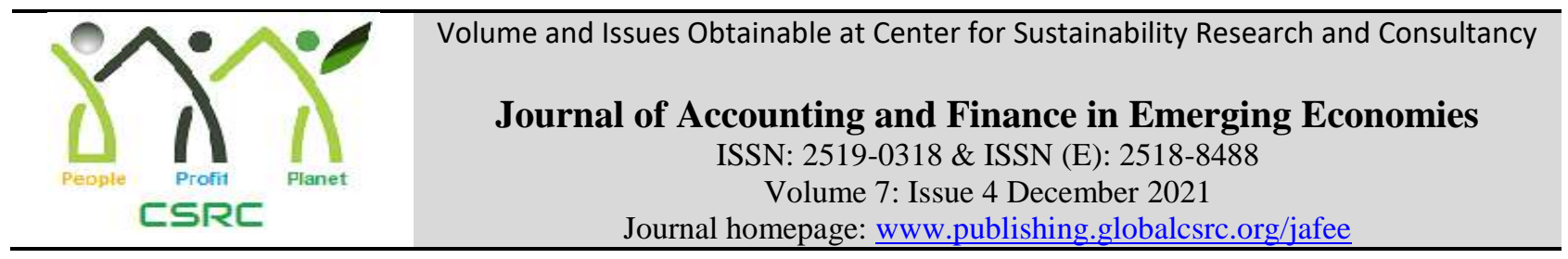

\title{
Factors of Customer Satisfaction in the Servicing Sector: Does Quality of Service Matter?
}

Muhammad Akbar Ali Ansari, Department of Commerce, The Islamia University of Bahawalpur, Pakistan

Muhammad Sajid, Department of Commerce, The Islamia University of Bahawalpur, Pakistan *Ali Junaid Khan, Institute of Business Management and Administrative Sciences, The Islamia University of Bahawalpur, Pakistan

Tanveer Ahmed, Department of Environmental Management, National College of Business Administration and Economics, Lahore, Pakistan

*Corresponding author's email: Junaaidkhan@yahoo.com

ARTICLE DETAILS

History

Revised format: Nov 2021

Available Online: Dec 2021

Keywords

Customer Satisfaction,

Financial Services Quality, Conventional Banking, cost

offinancing, customer, SEM

Square equation Model

JEL Classification

M1, M2

\section{ABSTRACT}

Purpose: The purpose of the study is to evaluate the influence of the cost of financing, customer loyalty, and customer security on customer satisfaction with financial services as moderating effects in the Pakistani context. This study aims to provide the financial services concept between the cost of customer loyalty, customer security, financing and customer satisfaction.

Methodology: Data is gathered through the use of a questionnaire. A total of 330 respondents from Pakistan's five largest banks participated in the study. The information gathered pertains to the various roles that bank personnel play on behalf of bank clients. The sample approach utilised in this study is a convenience sampling method. The SPSS program is used to evaluate the data on the demographics of the area. The PLS-SEM is used to investigate the conceptual model.

Findings: To achieve banking goals in the long term, financial service quality has a favorable effect on customer loyalty and satisfaction, as well as on the cost of financing. Even in the conventional banking sector, the quality of financial services is not adhered to. Financing prices, customer loyalty, customer security, and customer satisfaction all have a direct correlation to the quality of financial services.

Practical Implications: To generate high profits and productivity, financial organizations must develop the quality mechanisms to get the best results from customer satisfaction goals.

(C) 2021, The authors, under a Creative Commons AttributionNon Commercial 4.0

Recommended citation: Ansari, M. A. A., Sajid, M., Khan, A. J. and Ahmed, T. (2021). Factors of Customer Satisfaction in the Servicing Sector: Does Quality of Service Matter? Journal of Accounting and Finance in Emerging Economies, 7 (4), 897-911 


\section{Introduction}

Customer satisfaction is a major concern for all banks nowadays. In both the commercial and public sectors, customers satisfaction is a top priority. Achieving greater performance means meeting the requirements of both internal and external customers. (Rampersad, 2001). The bank's performance is heavily influenced by its ability to keep its customers happy (Samar Rahi, 2019). Bank profits are directly related to client happiness. Customer satisfaction, in addition to financial results, influences a company's worth and success (Hariyati, 2019). When customers are happy, companies perform better. According to the author (O'Sullivan, 2012), customers are satisfied when their expectations are met and their requirements are met for obtaining service quality, according to the researcher's perceptions and feelings (Anastasia Golovkova, 2019). Measuring service quality is intimately linked to customer satisfaction (Mehrdad Estiri, 2011).

As businesses seek to maintain their competitive edge in the marketplace, the problem of service quality is a significant one. The banking industry relies heavily on the quality of service to ensure customer satisfaction. The quality of financial services boosted the performance of the company (Rishi Kant, 2017; Khan \& Iqbal, 2020). Banks are using technology advancements to improve their individual and commercial customer service initiatives. Quality services are also associated with higher revenue, customer retention, a stronger cross-sell ratio, and customer satisfaction, which gives banks a significant marketing advantage. As a result, Pakistan's economy relies heavily on the banking industry (Thai, 2017). The agriculture sector generates the majority of Pakistan's export earnings and accounts for around a quarter of the country's total GDP (gross domestic product).

The State Bank of Pakistan and the World Bank have issued regulations on banks and money, and this has resulted in significant growth for Pakistan's banking sector (Prorokowski, 2017). New promotion services that were previously unavailable in Pakistan, including Visa, Electronic Bank Services, and Mobile Banking, are now being offered by banks in Pakistan (Cajetan I. Mbama, 2018). It is customary for financial organization to believe that their clients are at the heart of their services, and hence their operations are influenced by them. However, despite the fact that the banking business has been known to encounter service quality failures and not meet its primary objective (Khan, Tufail, \& Ali, 2021).

\section{Research Problem}

For the most part, Pakistani banks are still operating under the constraints of outdated software. As a result, their consumers receive substandard service because they lack skilled and experienced workers (Samraz Hafeez, 2012). The importance of customer satisfaction in reorganizing and restructuring capital has been highlighted in previous research, leading banks to seek out investment possibilities in order to remain competitive in the global banking market. In the financial services industry, customer satisfaction has received scant attention in the literature (Hussain, 2016).

Therefore, in this gap, this research empirically investigated the relationships between service quality, customer loyalty, cost of financing, customer satisfaction and with the moderating impact of the quality of financial service in the Pakistani's conventional bank customer's context.

\section{Significance of Study}

Banks in Pakistan are heavily dependent on government and state bank policies, a strategy that is not usually connected with customer satisfaction. For this reason, this research encourages practitioners to think creatively about how they might improve their customer service. Individuals, institutions, and parties interested in learning more about bank customers' behaviors can benefit from this research. The present political developments in Pakistan are critical in the effort to reform 
the country's banking sector, which was previously under the authority of an autocrat whose sole goal was to gain personal wealth at the expense of the country's economic development. Pakistani banks are striving to participate in investment operations in an effort to avert a return to the previous regime by regulating their dealings and reducing competition among financial institutions.

\section{Literature Review Customer Satisfaction}

Consumer loyalty is defined by Jamal and Naser (2002) as an individual's personal preference or assessment of a product or service's quality. When the arrangement of goods and ventures meets or exceeds customer wants, there is a result: consumer loyalty (Szymanski and Henard, 2001). Paying premiums, referring friends, and using additional products are all things that satisfied customers are eager to do (Reichheld, 1996). Banking success depends on customer loyalty. Consumer loyalty is essential to a bank's bottom line. "The impact of customer loyalty extends much beyond that of money in terms of influencing a firm's reputation and performance" (Le Saout \& Daher, 2016). To put it another way, loyalty is a good thing for your business and a good thing for your customers. In recent studies, it has been shown that customer loyalty and business execution have a favourable effect. For the time being, this concept is being overlooked (O'Sullivan, Customer Fulfillment, Profit, 2012).

\section{Customer Satisfaction and Service Quality}

Effective account management requires high levels of administrative quality in order to build customer loyalty. The firm's performance was boosted by the excellence of its financial management. Consumer loyalty in account management is examined in the evaluation of moneyrelated administrative excellence (Rishi Kant, 2017). Money management quality is dependent on the employee's attitude and on the management of the workforce. Top management is concerned about the quality of financial management in order to achieve the goal of customer loyalty (Elissavet Keisidou, 2013). Financial administration is provided by both public and commercial institutions to ensure customer loyalty. Observed administration quality was identified as the true piece of customer loyalty in the keeping money sector, which focuses on substance, dependability, confirmation, responsiveness, and bank image (Khan, Tufail \& Ali, 2021).

\section{The Banking Sector and Customer Satisfaction}

Among the several written studies on bank customer loyalty in Pakistan, one employed a benchmark that included bank customers from every region and every bank's resources (Elissavet Keisidou, 2013). Inquiries into the clients' satisfaction with the banks were part of the exam. The data was obtained in order to compare the customer satisfaction scores of banks that are interested in the monetary customer fulfillment list. The findings revealed that the most important features that result in fulfillment are reacting quickly to faults and having an amiable manager. The findings also revealed that the arrangement of good, individual administration is seen by consumers as more important than comfort or things (Wahedulhaq, 2014). Customers that participated in the consumer loyalty research purchased more things than those in the control group, according to a recent study conducted in Pakistan as well. When it comes to customers' perceptions of a business, researchers found that review interest was the driving force towards a more positive perception of the company (Gianfranco Walsh, 2008).

\section{Satisfaction and Loyalty of Customers}

In the money-saving area, customer loyalty is a top priority since it has a direct impact on administration quality and customer satisfaction. When it comes to customer loyalty, there are very few variables that might influence it. Each bank's major concern is retaining and increasing customer loyalty and steadfastness for its own financial gain (Helena Martins Gonçalves, 2012). A bank's ability to maintain a good relationship with its customers is now being recognized as a sign of good business operations and a positive attitude among its employees. Mail and survey data 
were used to compile this information. Committed and satisfied employees are more likely to work towards achieving organizational objective that leads to the greater performance of organization (Javeria et al., 2013; Junaid, Bashir, Nasim, \& Ahmad, 2021; Khan \& Iqbal, 2020)

\section{Satisfaction and Security of Customers}

Customers' loyalty to a bank is measured in part by how well it protects them. Researchers have found that the account management process revolves around a constant focus on security. An account exchange must be managed securely to reduce the risk to each individual client (Ames Andrew, 2014). Researchers used a meta-examination focused on safety and security as a starting point. Maintaining a safe distance from the dangers associated with bank transactions necessitates the presence of adequate protection for clients. According to a study (Ames and Andrew, 2014), consumer loyalty is directly influenced by the level of client security.

\section{Conceptual Framework of Customer Satisfaction}

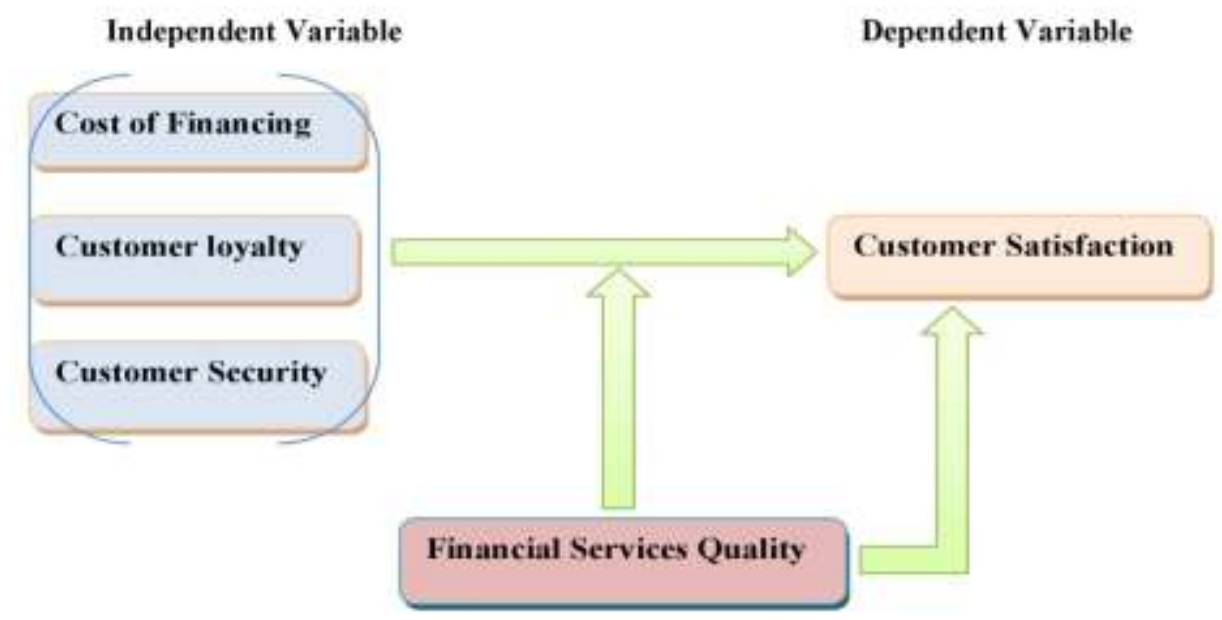

Figure 1: Conceptual Framework

\section{Hypotheses of the Research Model}

Following are the hypothesis that are based on the model and the purpose of the study:

H1: In the banking sector in Pakistan there is a positive relationship between customer satisfaction and customer cost.

H2: In the banking sector in Pakistan there is a positive relationship between customer satisfaction and customer loyalty.

H3: In the banking sector in Pakistan there is a positive relationship between customer satisfaction and customer security.

There is a positive relationship between financial service quality and customer satisfaction

H5: In the banking sector in Pakistan the quality of financial services moderates the relationship between customer satisfaction and customer cost of financing.

H6: Financial Services Quality moderates the relationship between customer loyalty and customer satisfaction.

H7: Financial Services quality moderates the relationship between customer satisfaction and 
customer security.

\section{Methodology}

The research design is based on the population and sample size of the study. The population of the study is unknown and includes all the customers of the banking sector in Pakistan. The researcher chooses five major Pakistani banks to fill in the study gaps and conduct data analysis. HBL, UBL, $\mathrm{MCB}$ and $\mathrm{ABL}$ are Pakistan's five largest banks. In order to get an accurate picture of how customers feel about these banks, we surveyed a small group of workers from each of them. More than 400 questionnaires were given to the respondents, 350 of which were returned and 330 of which were filled out correctly. The Smart PLS programme (Joseph F. Hair, 2014) and the Statistical Package for the Social Sciences (SPSS) software were used to evaluate the results (Arkkelin, 2014). The Smart PLS is used to assess all operational variables, while the SPSS programme is used for demographic analysis (Arkkelin, 2014).

\section{Sampling}

A thumb rule is used while interviewing survey subjects. The study's 330 completed surveys were a success. The sample size is 330 respondents, and the questionnaire data is gathered on the basis of 10 times the total number of items in the questionnaire. There are 10 times as many questions, according to Barclay et al. (1995). Respondents are staff of Pakistan's five largest banks, who are tasked with gauging customers' perceptions of them.

\section{Sampling Technique}

The sampling technique must be chosen at the conclusion of the sample part. It is necessary for a quantitative study to employ both random and convenient sampling methods in order to have a representative sample size. It is easier and less expensive to collect samples using the convenience sampling approach than it would be to utilize alternative methods. It is simple to collect data from a specific population by using convenience sampling.

\section{Instrument of Measurement}

In this section, all the variables are explained with the help of items for each variable. Customer satisfaction has eight items. Customer loyalty is evaluated on five items. Financial services quality has seven items. Customer security is evaluated on six items. The cost of financing is evaluated on the basis of the seven items. The questionnaire is designed on the basis of the five-likert scale with options from $1=$ Strongly Disagree, $2=$ Disagree, $3=$ Not Sure, $4=$ Agree, $5=$ Strongly Agree. The constructs and measurements of the questionnaire are represented in Table 1, which is mentioned below.

Table 1: Constructs and Measurements

\begin{tabular}{ll}
\hline Construct & \multicolumn{1}{c}{ Measurement } \\
\hline & CS 1 This Bank is exactly what customer need for their Business. \\
& CS 2 The product information presented by this Bank is accurate. \\
& CS 3 Privacy policies in this Bank are good. \\
Customer & CS 4 State Bank of Pakistan provides the guarantee of this Bank. \\
Satisfaction & CS 5 Customers are satisfied with the breadth of banking services. \\
& CS 6 Customer will be more satisfied if the bank offers Islamic financial services. \\
& CS 7 Customers are satisfied with the depth of customer services. \\
CS 8 overall, customer satisfaction level is good. \\
Loyalty & CL 1 Customer will always use this bank in their banking activities/ transactions. \\
& CL 2 Customer will say positive things about this bank to other people. \\
\end{tabular}


CL 4 Customer will never change this Bank even they found another bank like this.

CL 5 overall, customer loyalty is good.

FSQ 1 This Bank offers fast and efficient financial services.

FSQ 2 Provision of good financial services helps in retaining the customers.

$\begin{array}{ll}\text { Financial } & \text { FSQ } 3 \text { There is high degree of convenience in financial services of this bank as customer can } \\ \text { Services } & \text { acces the bank services from anywhere in Pakistan. } \\ \text { Quality } & \text { FSQ } 4 \text { This bank provides breadth of financial services. } \\ & \text { FSQ } 5 \text { This bank provides depth of financial services. } \\ & \text { FSQ } 6 \text { This bank's staff is friendly with the customers. } \\ & \text { FSQ } 7 \text { overall, financial services of this bank are good. } \\ & \text { CST 1 Customer feels safe when using this Bank. } \\ \text { CST } 2 \text { Performance of the staff is well and it's almost impossible that customer lose their money. } \\ \text { Customer } & \text { CST } 3 \text { The Bank cares about safety of its customers. } \\ \text { Security } & \text { CST } 4 \text { The bank is highly concerned with the security of customer transactions. } \\ & \text { CST } 5 \text { The Bank keeps the customer information secret. } \\ & \text { CST 6 overall, security arrangements are good at this bank. } \\ & \text { COF 1 Loan processing fee is high in this bank. } \\ \text { Cost } & \text { COF 2 Loan documentation charges are high in this bank. } \\ \text { Financing } & \text { COF } 3 \text { Legal charges are high in this bank. } \\ & \text { COF } 4 \text { Interest charges are high in this bank. } \\ \text { COF } 5 \text { Penalty for non- payment of loan is high in this bank. } & \text { COF } 6 \text { Insurance charges for sanctioning of loan are high in this bank. } \\ & \text { COF 7 Overall, cost of financing is high at this bank. }\end{array}$

Where CS $=$ Customer Satisfaction, CL $=$ Customer Loyalty, FSQ $=$ Financial Services Quality, CST = Customer Security, and COF $=$ Cost of Financing

\section{Results and Discussion \\ Demographic Information}

Demographic variables are termed "control variables." In the questionnaire, respondents' gender, age, marital status, bank, position in the bank hierarchy, working experience, education level, size of bank, and type of bank are asked.

\section{Questionnaire Design and Pretest}

The questionnaire technique is adopted for the collection of data for the dependent variable. In the current study, customer satisfaction is a dependent variable which is evaluated by eight items which are adapted after the conduction of interviews and discussion with the customers of five major banks in Pakistan. In the current study, three independent variables are evaluated. The first independent variable is cost of financing, which has seven items. The second is customer security, which is evaluated by six items. The third variable, customer loyalty, has five items. And the fourth variable, which is, moderator financial services quality, has five variables that are adopted after the conduction of interviews and discussion with the customers of five major banks in Pakistan. Reliability is checked through the use of the Smart PLS software (Joseph F. Hair, 2014).

For the pretest, 33 customers were contacted to obtain questionnaire responses from five major banks in Pakistan. I developed the questionnaire so that the questions are related to the variables and the flow of questions is correct. Also, the language of questions is also tested in this section.

\section{Data Gathering}

Customer satisfaction, loyalty, customer security, and the cost of financing and financial services quality are all characteristics that are studied in this research. Data is obtained by a five-likert scale questionnaire. Five major Pakistani banks, the NBP, HBL, UBL, MCB, and ABL banks gather data on behalf of their clients from the personnel of these institutions. People are given questionnaires and asked to fill them out in person with a bank employee on behalf of the client to ensure that they provide their permission to answer questions. For those individuals who are really busy, I've also looked through the questions to ensure their permission. 


\section{Data Analysis Techniques}

After the data has been collected, it is time to examine it. For data analysis (Arkkelin, 2014), Smart PLS-SEM (Partial Least Square) (Joseph F. Hair, 2014) and SPSS Statistic Package for Social Sciences (SPSS) are utilised in the study for data analysis (Arkkelin, 2014). SPSS is a statistical programme used in the social sciences for data analysis. Hair, Joseph F., 2014).Data analysis standards such as data consistency, reliability, and validity can be obtained by using Smart PLS. Other tests for data analysis include fit models, measurement models, path weighing schemes, factor loading, cross loading, reflective measurement models (EMM), and evaluation models (EMV), among others (Joseph F. Hair, 2014).

Throughout the chapter, PLS path models and all their procedural applications are introduced in the first section. The PLS models provide us with a practical application of the criteria of the models in the evaluation of the company's reputation (Joseph F. Hair, 2014).

The PLS-SEM allows the researcher to identify the reliability and consistency notions at the beginning of the PLS-SEM measurement models for the purposes of determining dependability and consistency.

\section{The Measurement Model}

It consists of the different measures that are applied for the measurement of the different formulas and items. The measurement model of the methodology is constrained to the following steps:

Internal Consistency Reliability (Cronbach Alpha)

Convergent Validity (Average Variance Extracted AVE)

Discernment Validity (Fornel-Larcker Criterion)

\section{Extracted Average Variance (AVE)}

Finding the convergent validity of the established constructs may be done using the average variance extracted model, which is a fundamental technique. An indicator's square outer loading are taken into account while calculating its grand mean. In other words, the AVE's average value is the construct's average value. For the AVE, the same rationale is used as for the other structures. AVE is standardized as an average value of 0.50 or above, which accounts for half of the constructed indicator's value. A different scenario is that the construct will have an incorrect value for AVE if it is less than 0.50. (Joseph F. Hair, 2014).

\section{Fornell-Larcker Criterion}

For determining discriminant validity, this is the second most commonly used method of measurement. Here, the construct and latent variable correlation AVE values are utilized to compare the square roots of their square roots (Joseph F. Hair, 2014). Because of this, each square root must have a bigger correlation with all the other constructs utilized in the analysis than it does with its own square root value (Joseph F. Hair, 2014). Using this method, you'll look for a construct that has a lot more variance with the corresponding indicator than any other value in the construct (Joseph F. Hair, 2014).

\section{Demographic Statistics}

Table 2: Demographic Statistics

\begin{tabular}{|l|l|r|r|}
\hline \multicolumn{3}{|c|}{} & \multicolumn{2}{|c|}{ Prequency } & Percent \\
\hline GENDER & & 276 & 83.6 \\
\hline & Male & 54 & 16.4 \\
\hline MARITAL STATUS & Female & 119 & 36.1 \\
& Single & 208 & 63.0 \\
\hline & Married & 1 & 0.3 \\
\hline & Divorced & 2 & 0.6 \\
\hline EDUCATION & Separated & 7 & 2.1
\end{tabular}




\begin{tabular}{|l|l|r|r|} 
& Intermediate & 6 & 1.8 \\
\hline & Bachelor & 44 & 13.3 \\
& Masters & 253 & 76.7 \\
\hline & MPhil & 18 & 5.5 \\
\hline & PhD & 2 & 0.6 \\
\hline BANK & NBP & 66 & 20.0 \\
& HBL & 66 & 20.0 \\
\hline & UBL & 66 & 20.0 \\
\hline & MCB & 66 & 20.0 \\
\hline & ABL & 66 & 20.0 \\
\hline POSITION & Branch Manager & 15 & 4.5 \\
& operation Manger & 46 & 13.9 \\
\hline & General Banking officer & 178 & 53.9 \\
\hline & Other & 91 & 27.6 \\
\hline EXPERIENCE & Less than 5 years & 104 & 31.5 \\
& 6 to 10 years & 174 & 52.7 \\
\hline & 11 to 15 Years & 27 & 8.2 \\
\hline & 16 and Above years & 25 & 7.6 \\
\hline & Total & 330 & 100.0 \\
\hline & Private & 254 & 77.0 \\
& Public & 76 & 23.0 \\
\hline TYPE OF BANK & Total & 330 & 100.0 \\
\hline & & &
\end{tabular}

According to Table 2, 83.6 percent of surveys were completed by male respondents, whereas 16.4 percent were completed by female respondents. According to the above table, respondents with the marital status single account for 36.1 percent of respondents, while respondents with the marital status married account for 63 percent. Based on the qualification level of the respondents from whom data was collected, it was determined that the majority of questionnaires were filled out by masters. The data demonstrates the population's literacy rate, indicating that the majority of respondents are educated. The masters' proportion is 76.7 percent, which is the highest in the evaluated data.

\section{Structure Equation Modeling (PLS-SEM Approach)}

The research study's result is arrived at using statistical procedures. During the study, Smart PLS software is used to do the data analysis. When analysing data in marketing investigations as previously said, Smart PLS is employed extensively (Mena, 2011). System 1 and System 2 of the PLS are the two main divisions. While Convince Based SEM was used for research analysis in the past, after discovering a few flaws in the CB-SEM, PLS-SEM was developed. Partially least squares structure, which has recently emerged as a more contemporary alternative in recent years (Mena, 2011). Smart PLS 3.0 is used to perform data analysis.

The smart PLS has put a lot of emphasis on meeting the demands of researchers by figuring out how to identify the implications of their findings, which is the root of the problem. Detailed instructions on how to utilise the PLS are supplied. Using the paper, researchers may do in-depth critical analysis, correctly evaluate study findings, and draw conclusions about the validity of those findings (Mena, 2011). Based on either reflective or formative models, the measuring model is either a combination of both or neither. For the purpose of selecting candidates, Oliver G. otz (2010) used theoretical work to determine whether to use the formative or reflective approach.

\section{Factor Loading}

Factor loading is a method for determining an item's reliability. The standard rule of thumb for factor loading is a number greater than 0.60 or above (Joseph F. Hair, 2014). Whenever the individual factor loading value exceeds 0.60 , each item must be examined for factor loading. The PLS SEM was used to determine the outer loading values of all the study data. The validity and reliability of constructs are shown in Table 3. Furthermore, the validity and dependability of the 
data seem to be white noise.

Table 3: Construct Validity and Reliability

\begin{tabular}{lcc}
\hline Variable & Cronbach's Alpha & Composite Reliability \\
\hline CL & 0.746 & 0.809 \\
COF & 0.881 & 0.908 \\
CS & 0.890 & 0.912 \\
CST & 0.864 & 0.897 \\
FSQ & 0.799 & 0.858 \\
\hline
\end{tabular}

CL = Customer Loyalty, COF $=$ Cost of Financing, $C S=$ Customer Satisfaction, CST $=$ Customer Security, FSQ= Financial Services Quality

In the second step the researcher have to focus on the AVE value. The average variance model value AVE is the form of convergent validity, the paper defines the convergent validity according to the classical theory test which suggests that convergent validity value is between the correlations of the same constructs(Oliver $G^{*}$ otz, 2010). Therefore while measuring the AVE value the researcher face many problems for the evaluation of the variance for the same construct. AVE focus the variance of the indicators from the construct related to the total amount of variance, the calculated variance includes the measurement error(Oliver G*otz, 2010). The rule of thumb for the AVE is if the value is below 0.5 it is considered as insufficient value above 0.5 is accepted(Oliver G*otz, 2010). The AVE values are mentioned below in the Table 4.

Table 4: Average Variance Extracted

\begin{tabular}{lc}
\hline Variable & Average Variance Extracted (AVE) \\
\hline CL & 0.586 \\
COF & 0.585 \\
CS & 0.567 \\
CST & 0.594 \\
FSQ & 0.501 \\
Moderating Effect 1 & 1.000 \\
Moderating Effect 2 & 1.000 \\
Moderating Effect 3 & 1.000 \\
\hline
\end{tabular}

CL = Customer Loyalty, COF $=$ Cost of Financing, CS= Customer Satisfaction, CST= Customer Security, FSQ= Financial Services Quality

Table 8 indicates the AVE values for the discriminant validity for the Customer loyalty 0.586, AVE value for the cost of financing 0.585 and AVE value for the customer satisfaction is $0.567, \mathrm{AVE}$ value for the customer security 0.594 and the AVE value for the moderator financial services quality 0.501 . The rule of thumb for the AVE average variance extracted is 0.5 . All the values in the table 8 are above from the standard value 0.5 it clarify that the data is according to the rule of thumb.

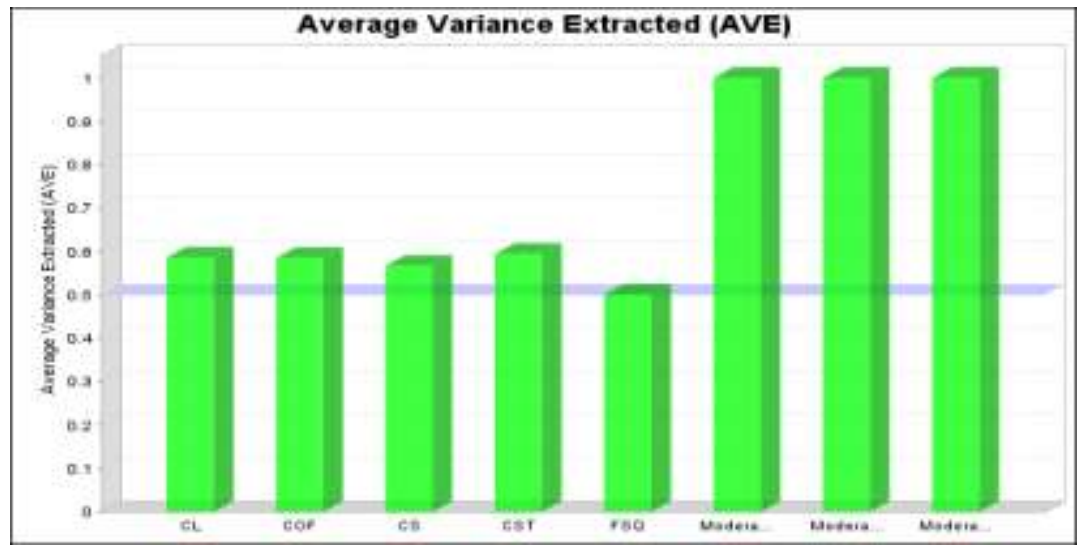

Figure 2: Average Variance Extracted 
AVE discriminant validity values are shown in Figure 2 based on the values computed for the various constructs. For the AVE variance, the table shows that all of the bars are over the median line of 0.5 . The bars for customer loyalty, cost of financing, customer satisfaction, customer security, and the quality of financial services are all above the mean point, while the bar for moderating effects is close to the 1.0 mark, indicating that the moderator has a positive effect on all independent variables. There are no discrepancies in the AVE values shown in Figure 2, which means the study is genuine.

\section{Cross Loading}

The cross loading approach along with AVE values is used to determine the discriminant validity. Every loading has an indication with a higher value than the one meant to load, according to this rule (Mena, 2011). When employing the Fornell-Larcker, the AVE should be greater than the other correlation in order to verify the discriminant validity. Cross loading or the Fornell-Larcker technique may be used to process the rule of thumb (Mena, 2011). Table 5 shows the cross loading values derived using Partial Least Squares (PLS).

Table 5: Cross Loading

\begin{tabular}{|c|c|c|c|c|c|}
\hline Variable & CL & COF & $\mathrm{CS}$ & CST & FSQ \\
\hline $\mathrm{CL} * \mathrm{FSQ}$ & -0.564 & -0.248 & -0.595 & -0.213 & -0.557 \\
\hline CL2 & 0.760 & 0.290 & 0.564 & 0.274 & 0.427 \\
\hline CL4 & 0.826 & 0.310 & 0.634 & 0.330 & 0.565 \\
\hline CL5 & 0.706 & 0.317 & 0.502 & 0.341 & 0.642 \\
\hline $\mathrm{COF} * \mathrm{FSQ}$ & -0.320 & -0.317 & -0.322 & -0.336 & -0.418 \\
\hline COF1 & 0.360 & 0.765 & 0.437 & 0.701 & 0.454 \\
\hline COF2 & 0.258 & 0.789 & 0.426 & 0.480 & 0.410 \\
\hline COF3 & 0.270 & 0.807 & 0.364 & 0.492 & 0.324 \\
\hline COF4 & 0.268 & 0.770 & 0.407 & 0.594 & 0.420 \\
\hline COF5 & 0.276 & 0.747 & 0.371 & 0.537 & 0.298 \\
\hline COF6 & 0.290 & 0.776 & 0.369 & 0.522 & 0.367 \\
\hline COF7 & 0.401 & 0.695 & 0.382 & 0.482 & 0.421 \\
\hline CS1 & 0.522 & 0.428 & 0.760 & 0.397 & 0.520 \\
\hline $\mathrm{CS} 2$ & 0.532 & 0.467 & 0.783 & 0.416 & 0.561 \\
\hline $\mathrm{CS} 3$ & 0.655 & 0.415 & 0.812 & 0.384 & 0.612 \\
\hline CS4 & 0.412 & 0.242 & 0.606 & 0.298 & 0.377 \\
\hline CS5 & 0.566 & 0.337 & 0.764 & 0.402 & 0.508 \\
\hline CS6 & 0.550 & 0.347 & 0.743 & 0.384 & 0.498 \\
\hline CS7 & 0.607 & 0.391 & 0.761 & 0.384 & 0.546 \\
\hline CS8 & 0.603 & 0.456 & 0.777 & 0.466 & 0.530 \\
\hline $\mathrm{CST} * \mathrm{FSQ}$ & -0.270 & -0.330 & -0.333 & -0.410 & -0.330 \\
\hline CST1 & 0.341 & 0.733 & 0.461 & 0.772 & 0.477 \\
\hline CST2 & 0.268 & 0.569 & 0.429 & 0.760 & 0.323 \\
\hline CST3 & 0.335 & 0.567 & 0.400 & 0.831 & 0.393 \\
\hline CST4 & 0.252 & 0.352 & 0.235 & 0.637 & 0.265 \\
\hline CST5 & 0.329 & 0.471 & 0.329 & 0.791 & 0.334 \\
\hline CST6 & 0.355 & 0.530 & 0.477 & 0.820 & 0.423 \\
\hline FSQ1 & 0.689 & 0.409 & 0.623 & 0.441 & 0.735 \\
\hline FSQ2 & 0.596 & 0.358 & 0.483 & 0.332 & 0.761 \\
\hline FSQ3 & 0.525 & 0.393 & 0.521 & 0.398 & 0.817 \\
\hline FSQ4 & 0.459 & 0.309 & 0.413 & 0.306 & 0.730 \\
\hline
\end{tabular}




\begin{tabular}{lccccc} 
FSQ5 & 0.435 & 0.456 & 0.517 & 0.404 & 0.801 \\
FSQ6 & 0.487 & 0.378 & 0.574 & 0.336 & 0.737 \\
FSQ7 & -0.047 & 0.004 & -0.001 & 0.024 & 0.019 \\
\hline
\end{tabular}

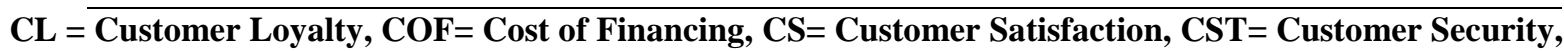
FSQ $=$ Financial Services Quality

\section{Fornell-Larcker Criterion}

Discriminant validity may be demonstrated by comparing the latent variable AVE to the squared correlations of the squared correlations that are connected to the construct's latent variable AVE (Mena, 2011). The reflecting measurement validation procedure was finished when the discriminant validity process was completed. The reflecting measurement model illustrates that this is the conclusion of the whole validation procedure for the constructs. Table 6 displays the results of the study as they were obtained using the PLS SEM and its output graph 3.0outputs and Fornell-Larcker values.

Table 6: Fornell-Larcker Criterion

\begin{tabular}{lllllllll}
\hline Variable & CL & COF & CS & CST & FSQ & $\begin{array}{l}\text { Moderating } \\
\text { Effect 1 }\end{array}$ & $\begin{array}{l}\text { Moderating } \\
\text { Effect 2 }\end{array}$ & $\begin{array}{l}\text { Moderating } \\
\text { Effect 3 }\end{array}$ \\
\hline CL & 0.766 & & & & & & & \\
COF & 0.397 & 0.765 & & & & & \\
CS & 0.744 & 0.518 & 0.753 & & & & \\
CST & 0.409 & 0.716 & 0.522 & 0.771 & & & \\
FSQ & 0.705 & 0.507 & 0.695 & 0.490 & 0.708 & & \\
Moderating & -0.320 & -0.317 & -0.322 & -0.336 & -0.418 & 1.000 & \\
Effect 1 & -0.564 & -0.248 & -0.595 & -0.213 & -0.557 & 0.527 & 1.000 & \\
$\begin{array}{l}\text { Moderating } \\
\text { Effect 2 }\end{array}$ & -0.270 & -0.330 & -0.333 & -0.410 & -0.330 & 0.862 & 0.486 & 1.000 \\
$\begin{array}{l}\text { Moderating } \\
\text { Effect 3 }\end{array}$ & -0.230 & \\
\hline
\end{tabular}

CL = Customer Loyalty, COF $=$ Cost of Financing, CS= Customer Satisfaction, CST $=$ Customer Security, FSQ $=$ Financial Services Quality

After the Fornell Larcker measures, Table 10 indicates the values acquired, which are bold in the table, which illustrates the criterion specified for the correlations that the squared value of each AVE of a certain construct is greater than the other construct value (Joseph F. Hair, 2014). According to the table, each construct has a higher correlation than the other constructs. 


\section{Structure Model}

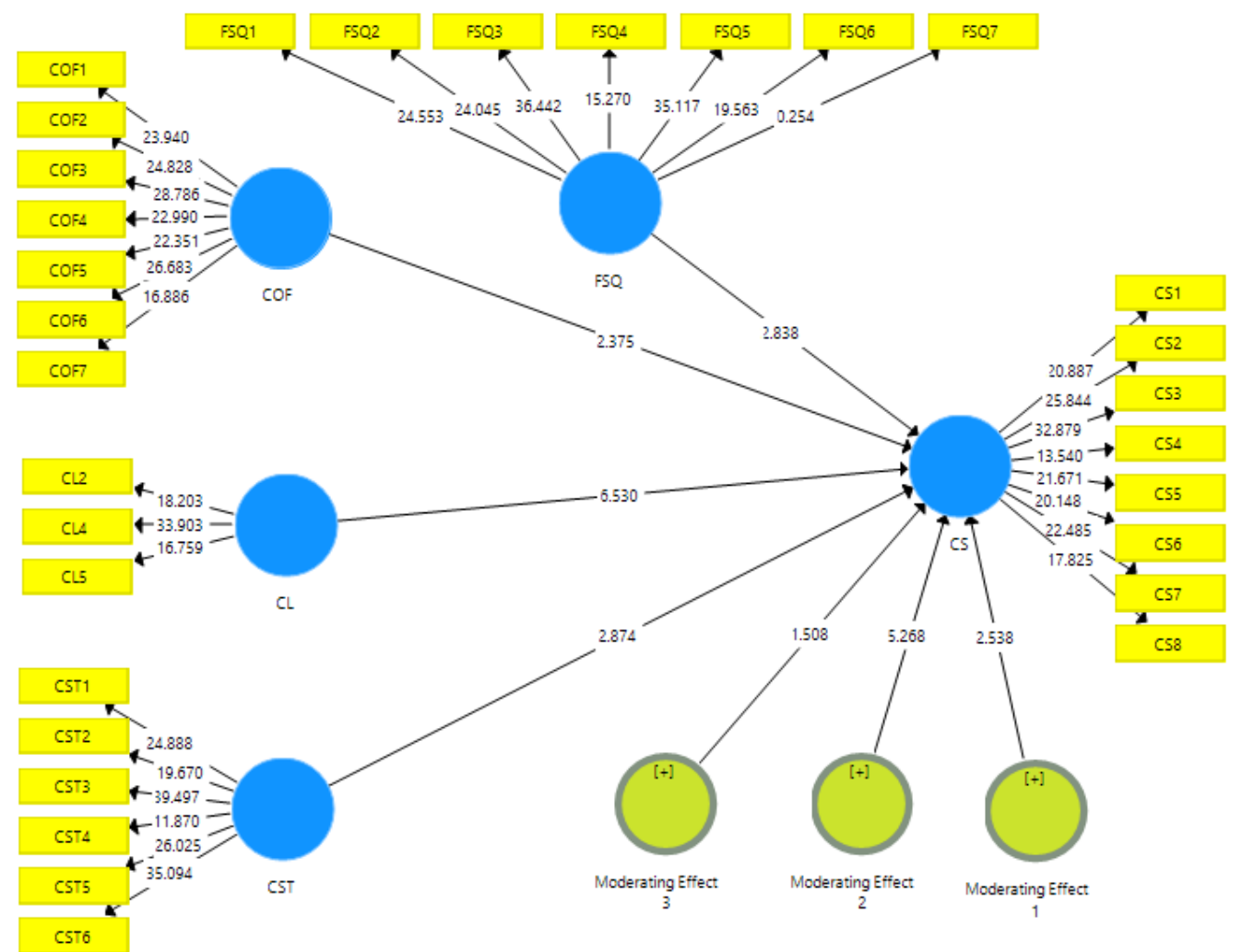

Figure 3: Structure Model

The factor loading values for the individual indicators for the constructs employed in the study are shown in Figure 3. A value higher or equal to 0.7 implies that all constructions are positive and conform to industry standards, as seen in figure 3. Figure 3 illustrates a positive moderator relationship; in this example, the moderator is the quality of financial services. As seen by the moderate variable's value of 2.538 , the moderator has a moderate value.

Factor loading values for some constructs are removed which have the values below 0.4 are removed from the study. Financial services quality has the seven constructs as per the factor loading. The constructs includes for the customer satisfaction include eight items as per the factor loading., cost of financing constructs the seven items, customer loyalty construct the three items and customer security construct the six items whose values are determined after the values of factor loading.

\section{Conclusion}

There was a significant relationship between the study's primary goal and its secondary goal, and both were met. The customer satisfaction is the most important consideration in this study of conventional banks. Customers' levels of satisfaction in Pakistani commercial banking were examined in depth. This finding suggests that customer loyalty is the most important influence on customer satisfaction. According to the findings, customer satisfaction rises when the cost of financing the bank's product is minimal. In addition to improving the independent variable, customer happiness, ensuring customers' safety has a favourable effect on it as well. The quality of financial services is employed as a moderator in this study, which has a substantial influence on the independent variables: cost of financing, customer loyalty, and customer security, and the dependent variable, consumer happiness (Daniel J. Petzer, 2017).

That banking is a crucial part and financial services quality is critical in the banking sector of 
Pakistan is evident from this study's findings. No bank can achieve customer happiness unless it improves the quality of its financial services (Dibrova, 2017). Methods for maximization the use of financial resources for the betterment of society are numerous. It was decided to apply the Data Envelope Analysis (also known as the DEA method) for the analysis of the research article.

\section{Policy Recommendations}

There is additional motivation for practitioners in this study because of the researcher's emphasis on finding new ways of improving customer service and pursuing change in the services supplied. The findings of this study suggest the best strategies for managers to apply in their organizations in order to make the most of the company's financial resources.

\section{Limitations and Future Directions}

Only five main Pakistani banks were examined in this study owing to a lack of resources and time. However, a similar study might be undertaken in the future among Pakistan's other bank clients and in scenarios from across the world. This analysis relied on information from Pakistan's five largest banks because of a lack of resources and a timing crunch. In terms of gender-based research, the data obtained from both male and female respondents is not evenly distributed across the two primary sexes. In the future, data from respondents from both the dominant sexes might be collected on an equality basis. For the time being, the data is only gathered from medium and largesized and private/public institutions, but in the future, it may be collected from smaller and overseas institutions. In the fifth and final section, the questionnaire technique is used to gather data; in the future, other data collection methods may be used, such as the survey-based approach or the quantitative form of data collecting.

\section{References}

Ahmad Y. Khasawneh, Q. A. (2017). Sales nationality and debt financing impact on firm's performance and risk:. EuroMed Journal of Business , pp.103-126.

Anastasia Golovkova, J. E., Aleksandra Malova, Olga Podkorytova. (2019). Customer satisfaction index and financial performance: a European cross country study. International Journal of Bank Marketing. doi: 10.1108/IJBM-10-2017-0210

Akroush, M. N. (2012). Internal marketing and service quality in restaurants. Marketing Intelligence \& Planning, 35 .

ames Andrew, T. T. (2014). Defence and security: new issues and impacts. Foresight , pp.165-175.

Arkkelin, D. (2014). Using SPSS to Understand Research and Data Aanalysis (Vol. http://scholar.valpo.edu/psych_oer). (D. ". Arkkelin, Ed.) Valparaiso University,

Cajetan I. Mbama, P. O. E. (2018). Digital banking, customer experience and bank financial performance: UK customers' perceptions. International Journal of Bank Marketing. doi: 10.1108/IJBM-11-2016-0181

Daniel J. Petzer, C. F.-H. (2017). Perceived justice, service satisfaction and behavior intentions following service. International Journal of Bank Marketing , pp.241-253.

Dibrova, a. (2017). Analysis of crowdfunding in european union performance and perspectives. Emerald group publishing limited .

Daniel J. Petzer, C. F. D. M.-H., Göran Svensson. (2017). Perceived justice, service satisfaction and behavior intentions following service. International Journal of Bank Marketing, pp.241-253.

Elissavet Keisidou, L. S. a. D. I. M. (2013). Customer satisfaction, loyalty and financial performance A holistic approach of the Greek banking sector. International Journal of Bank Marketing, 31(4), 259-288. doi: 10.1108/IJBM-11-2012-0114

Hariyati, B. T., Noorlailie Soewarno. (2019). The mediating effect of intellectual capital, management accounting information systems, internal process performance, and customer performance. International Journal of Productivity and Performance Management. doi: 10.1108/IJPPM-02-2018-0049 
Hedman, E. (2016, March). Leadership Team Tool for better meaning making. Emraled , 15.

Helena Martins Gonçalves, P. S. (2012). The customer satisfaction-customer loyalty relationship: Reassessing customer and. Management Decision , pp.1509-1526.

Hubert Rampersad. (2001). 75 painful questions about your customer satisfaction. The TQM Magazine .

Hussain, R. (2016). The mediating role of customer satisfaction. Asia Pacific Journal of Marketing and Logistics , pp.234-255.

Javeria, A., Rizwan, M., Khan, A., Hameed, A., Neem, Q., \& Subctageen, M. (2013). Examining the Antecedents of Job Satisfaction and further its impact on Organizational Commitment. Journal of Public Administration and Governance, 3(3), 317-334.

Junaid, A., Bashir, F., Nasim, I., \& Ahmad, R. (2021). Understanding Affective, Normative \& Continuance Commitment through the Lens of Training \& Development. iRASD Journal of Management, 3(2), 105-113.

Joseph F. Hair, J. M. (2014). A premier on Partial Least Squarse Structural Equation Modeling (SEM) . In J. M. Joseph F. Hair, A premier on Partial Least Squarse Structural Equation Modeling (SEM) (p. 389).

Khan, A. J., \& Iqbal, J. (2020). Do High Performance Work Practices Increase the Organizational Performance of Public Sector Companies? An Investigation of Mediation Mechanism. Pakistan Journal of Social Sciences (PJSS), 40(2), 1007-1021.

Kai Hoberg, M. P.-S. (2017). How do financial constraints and financing costs affect inventories? www.emeraldinsight.com, Vol. 47 Iss 6 pp.

Khan, A. J., \& Iqbal, J. (2020). Training and Employee Commitment: The Social Exchange Perspective. Journal of Management Sciences, 7(1), 88-100.

Khan, A. J., Tufail, S., \& Ali, A. (2021). Factors Affecting Performance of Small \& Medium Enterprises: The Mediating Role of Knowledge Management. Pakistan Journal of $\begin{array}{lllll}\text { Humanities } \& \quad \text { Social } & \text { Sciences, } & 9(2),\end{array}$ doi:https://doi.org/10.52131/pjhss.2021.0902.0129

Luciano Munari, F. I. (2013). Customer satisfaction management in Italian banks. Qualitative Research in Financial Markets , pp.139-160.

Malcolm Pattinson, M. B. (2017). Managing information security awareness at an Australian bank: a comparative. Information \& Computer Security , pp.181-189.

Mehrdad Estiri, F. H. (2011). Determinants of customer satisfaction in Islamic banking: evidence from Iran. International Journal of Islamic and Middle Eastern Finance and .

Mena, J. F. (2011, June 7). An assessment of the use of partial least squares structural equation modeling in marketing research. Springer , 20.

Min-Hsin Huang, Z.-H. C. (2016). A longitudinal comparison of customer satisfaction and customer-company. Journal of Service Management .

Moreno Muffatto, R. P. (1995). A process-based view for customer satisfaction. International Journal of Quality \& Reliability Management .

o’Sullivan, D. (2012). Customer satisfaction, earnings. European Journal of Marketing .

oliver G“otz, K. L.-G. (2010). Evaluation of Structural Equation Models Using the Partial Least Squares (PLS) Approach. (S.-V. B. 2010, Ed.) DoI 10.1007/978-3-540-32827-8 30, (DoI 10.1007/978-3-540-32827-8 30,), 24.

Prorokowski, L. (2017). Shadow banking regime: assessment of investment funds. Journal of Investment Compliance, 18(2), 36-45. doi: 10.1108/joic-04-2017-0024

Quico Marin-Anglada, F. C.-P.-L. (2014). Analysis of the profitability of the Spanish business sector with investment presence in China. www.emeraldinsight.com, Vol. 18 Iss 3 pp. 122.

Rainer Masera, G. M. (2016). on the non-neutrality of the financing policy and the capital regulation of banking. Studies in Economics and Finance , pp.466-487.

Rishi Kant, D. J. (2017). The impact of perceived service quality dimensions on customer satisfaction: An. International Journal of Bank Marketing , pp.411-430. 
Rampersad, H. (2001). 75 painful questions about your customer satisfaction. The TQM Magazine.

Rishi Kant, D. J. (2017). The impact of perceived service quality dimensions on customer satisfaction: An. International Journal of Bank Marketing, pp.411-430.

Samraz Hafeez, B. M. (2012). The Impact of Service Quality, Customer Satisfaction and Loyalty Programs on Customer's Loyalty. International Journal of Business and Social Science .

Samar Rahi, M. M. O. M., Mahmoud Alghizzawi and Feras Mi Alnaser. (2019). Integration of UTAUT model in internet banking adoption context: The mediating role of performance expectancy and effort expectancy. Journal of Research in Interactive Marketing, 13(3), 411435. doi: 10.1108/JRIM-02-2018-0032

Stephanie Hui-Wen Chuah, P. A. (2017). Why do satisfied customers defect. Journal of Service Theory and Practice .

Temesgen Kitaw Damenu, C. B. (2017). Analysing Information Security in a Bank using Soft Systems Methodology. Information \& Computer Security .

Victoria Bellou, A. A. (2017). organizational service orientation and job satisfaction: A multidisciplinary. EuroMed Journal of Business , pp.73-86.

Vinita Kaura, C. S. (2015). Service quality, service convenience, price and fairness, customer loyalty, and the. International Journal of Bank Marketing, pp.404-422.

Volker Seiler, M. R. (2013). The influence of socio-demographic variables on customer satisfaction and loyalty in the. International Journal of Bank Marketing, pp.235-258.

Wa h e e d u $1 \mathrm{~h} \mathrm{a} \mathrm{q,} \mathrm{B.} \mathrm{b.} \mathrm{(2014).} \mathrm{Measuring} \mathrm{the} \mathrm{level} \mathrm{of} \mathrm{Customer} \mathrm{satisfaction} \mathrm{in} \mathrm{Banking} \mathrm{sector.}$ Developing Country Studies .

Zalfa Laili Hamzah, S. P. (2017). Elucidating perceived overall service quality in retail banking. International Journal of Bank Marketing . 